\title{
Clinical, histological and cytogenetic observations on nine intersex dogs
}

\author{
S Chaffaux ${ }^{1}$, EP Cribiu ${ }^{2}$ \\ 1 ENVA, Laboratoire de Pathologie de la Reproduction, 94704 Maisons-Alfort; \\ ${ }^{2}$ INRA, Centre de Recherche de Jouy-en-Josas, \\ Laboratoire de Cytogénétique, 78350 Jouy-en-Josas, France
}

(Proceedings of the 9th European Colloquium on Cytogenetics of Domestic Animals; Toulouse-Auzeville, 10-13 July 1990)

intersex / dogs / cytogenetics / histology

\section{INTRODUCTION}

Alterations in the normal differentiation patterns of gonads, genital ducts and/or external genitalia usually result in intersexuality. Intersex animals are usually considered hermaphrodites with genital organs showing features of both sexes. They are classified as true hermaphrodites, male pseudohermaphrodites or female pseudohermaphrodites, according to the type of gonadal tissue expressed.

In this report, cases of intersexuality observed in dogs are discussed. A total of 9 dogs were presented for consultation at the Ecole Nationale Vétérinaire d'Alfort: 3 female Bearded collies (1,2 and 3), 10-11 months old, from a litter of 5 animals also including 2 normal males; 1 female Basset artésien (4) $21 / 2$ years old, from a litter of 8 animals ( 5 males, 3 females); 1 small fox-like crossbred female (5), 8 years old; an 8 year old German shepherd (6); 1 middle-sized Schnauzer aged 9 years (7); 1 one year old German shepherd (8); 1 crossbred spaniel aged one year (9).

Karyotypes of these dogs were determined on the basis of the results of whole blood (all of them) and gonadal cultures (1,2,3 and 5). Gonads and genital tracts from all the animals were fixed in Bouin's fluid. Histological sections were stained with hematoxylin-eosin.

\section{CASE REPORTS}

Out of nine animals, four (1-4) had a female karyotype (78,XX), four (5-8) were males $(78, \mathrm{XY}$ ), and case 9 was $78, \mathrm{XX} / 78, \mathrm{XY}$ (Chaffaux et al, 1980, 1986, 1990; Chaffaux and Cribiu, 1990). These animals were classified according to their karyotypes and type of intersexuality. 


\section{Female pseudohermaphrodites $78, \mathrm{XX}$}

Examination of the genital tracts of three females (1,2 and 3) revealed small and narrow vulvae with whitish mucosa located ventrally. A skin fold forming a sheathlike structure appeared to extend caudally from the vulva. The internal genital tract was similar in appearance to that of normal females. The vagina (5-6 cm long) was distended and filled with urine in every tract examined. Corpora lutea were present on the ovaries.

These cases of intersexuality resulted from the administration of anabolic steroids with strong androgenic activity (Dynabolon ND: nandrolone undecanoate) to the mother during pregnancy. These androgens had masculinized the external genital tract resulting in an increased anogenital distance.

\section{Male pseudohermaphrodite $78, \mathrm{XX}$}

The external genital tract of animal 4 showed a vulva normal in length, shape and position, and a $5 \mathrm{~cm}$ long peniform clitoris. Exploratory laparotomy revealed the presence of two gonads $(2 \times 1 \mathrm{~cm})$ in the subrenal region, symmetrical, of ovoid shape and with a smooth surface. They were not covered by a bursa but were dominated by a tubular structure reminiscent of an epididymis and a pampiniform vascular structure. Two uterine horns $(7 \times 0.6 \mathrm{~cm})$ fused to form a uterine body followed by a poorly defined cervix. The vagina had a very narrow diameter $(<0.5 \mathrm{~cm})$ similar to that of the urethral opening. Both structures were followed for 3 to $4 \mathrm{~cm}$ by a common duct, before arriving at the vestibula. In the clitoridian fossa, a peniform clitoris showed a well-developed os penis and corpora cavernosa.

Histological sections of the gonads showed structures similar to those of immature testis (only Sertoli cells were present in the epithelium of the seminiferous tubules). Germ cells were totally absent. The glandular interstitial tissue was reduced. A canalicular complex similar to the rete testis was prominent and was prolonged by an epididymal-like structure.

\section{True hermaphrodite 78,XY}

The external genitalia of female 5 included a small vulva in a normal position, a voluminous peniform clitoris with an os penis and a narrow vagina.

The internal genitalia included a uterus of normal size and shape, an ovary with a stroma full of atretic follicles devoid of oocytes and a voluminous hyperplastic gonad, with seminiferous tubules devoid of germ cells, and dominated by an epididymis. This gonad carried a testicular tumor (Sertoli cell tumor) frequently observed in dogs in cases of ectopic testis.

\section{Male pseudohermaphrodite 78,XY}

Dog 6 showed two testes of normal consistency and volume, in a scrotal position; the two epididymides were soft and slighty enlarged; the penis was short and the frenulum was present. Exploratory laparotomy revealed an internal genital tract 
consisting of a uterus. In the seminiferous tubules, spermatogenesis was arrested at the spermatocyte stage.

Examination of the genital tract of $\operatorname{dog} 7$ showed a normal sheath and a normal penis, a testis in the left scrotum, with a variable consistency. The right testis was absent. The internal genital tract included two uterine horns and two gonads; histology showed that the scrotal testis was degenerated, whereas the right testis had a Sertoli cell tumor.

The anterior half of the sheath of $\operatorname{dog} 8$ was absent, the penis was free and exposed to trauma and licking. There was no urethral meatus at the tip of this organ. The opening was situated in the perineal region under the anus (hypospadias) surrounded by a rudimentary vulva. The scrotum was formed by two skin folds in the internal aspect of the thighs. Testes were present in these folds and were of normal consistency and size. Spermatogenesis was active in both gonads. No exploratory surgery was performed.

\section{Female pseudohermaphrodite $78, \mathrm{XX} / 78, \mathrm{XY}$}

Dog 9 was a spaniel, showing a genital tract which included a penis of reduced size with an os penis $3 \mathrm{~mm}$ in diameter that could not be externalized. An empty rudimentary scrotum was situated at the median line. Exploratory laparotomy revealed a uterine body contiguous to the bladder and two uterine horns connected to two small gonads in a sublumbar position.

Histological examination showed that these gonads were ovaries containing a reduced number of follicles, some of them in the process of maturation.

\section{DISCUSSION}

The classical hypothesis involves a Y-linked gene, TDF in man, or $T D Y$ in mouse, responsible for testis formation. In the absence of a $\mathrm{Y}$ chromosome, genes coding for ovary formation are activated (Page et al, 1987). Testis formation is followed by the development of Sertoli cells, Leydig cells and male germ cells. The absence of germ cells results in complete sterility in the cases of intersexuality observed in this study. That sterility could be germ cell degradation due to a disequilibrium in $\mathrm{X}$ dosage. In the testis, the presence of more than one $\mathrm{X}$ gonosome results in degeneration of the germ cells (case 4).

In the ovary, both $\mathrm{X}$ chromosomes are euchromatic and active in oogonia and oocytes. A deficiency in X dosage (case 5) could induce poor follicular development and accelerate oocyte degradation. Fetal germ cells usually degenerate at the end of the fetal period and at birth. All oocytes would have disappeared at puberty in species with a long interval between oocyte formation and ovulation (Lyon and Hawker, 1979).

Sertoli cells secrete the anti-Müllerian hormone (AMH) responsible for the regression of Müllerian ducts and perhaps for the inhibition of follicular development (Vigier et al, 1987). The presence of developed derivatives of the Müllerian ducts in female pseudohermaphrodites suggests the absence of production of the AMH (case 9 ). In contrast, the presence of testicular tissue in male pseudohermaphrodites is 
not necessarily associated with an inhibition of Müllerian ducts by AMH (cases 4, 5,6 and 7); that hormone might not have been produced by the Sertoli cells or not been recognized by target organs.

Formation of the derivatives of the Wolffian ducts is stimulated by testosterone secreted by Leydig cells. However, Wolffian duct derivatives do not require the formation of a testis, since exogenous sources of testosterone can exist in female pseudohermaphrodites (cases 1,2 and 3).

Clitoris hypertrophy and resemblance to a penis (cases 4 and 5) indicate the postnatal production of testosterone, since the formation of the os penis implicates the fusion of two bones, 5 to 10 weeks after birth, and is under the control of testosterone and growth hormone.

\section{REFERENCES}

Chaffaux S, Cribiu EP (1990) Pseudohermaphrodisme femelle d'origine iatrogène chez trois chiennes d'une même portée. Recl Méd Vét 166, 407-411

Chaffaux S, Mailhac JM, Cribiu EP, Popescu CP, Cotard JP (1980) L'intersexualité chez le chien (Canis familiaris). A propos de quatre cas. Recl Méd Vét 156, 179-192

Chaffaux S, Cribiu EP, Crespeau F (1986) Un cas rare d'hermaphrodisme vrai latéral chez une chienne 78,XY. Recl Méd Vét 162, 463-470

Chaffaux S, Nudelmann N, Durand V, Cribiu EP (1990) Le pseudohermaphrodisme mâle, à propos du cas d'un chien intersexué 78,XX. Recl Méd Vét 166, 125-132

Lyon MF, Hawker SG (1979) Reproductive lifespan in irradiated and unirradiated chromosomally XO mice. Genet Res 21, 185-194

Page DC, Mosher R, Simpson EM, Fisher EMC, Mardon G, Pollack J, McGillvray B, De La Chapelle A, Brown LG (1987) The sex-determining region of the human Y chromosome encodes a finger protein. Cell 51, 1091-1104

Vigier B, Warin F, Magre S, Tran D, Josso N (1987) Purified bovine AMH induces a characteristic freemartin effect in fetal rat prospective ovaries exposed to it in vitro. Development 100, 43-55 